GRASAS Y ACEITES $72(1)$

January-March 2021, e398

ISSN-L: 0017-3495

https://doi.org/10.3989/gya.0103201

\title{
Catalyst-free production of fatty acid ethyl esters (FAEE) from macauba pulp oil
}

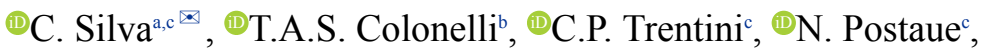 \\ DD.A. Zempulskic, ${ }^{D}$ L. Cardozo-Filho ${ }^{c}$ and $\mathbb{D}^{\mathrm{E}}$ E.A. Silva ${ }^{\mathrm{b}}$ \\ aDepartamento de Tecnologia, Universidade Estadual de Maringá (UEM), Av. Angelo Moreira da Fonseca 180, Umuarama, PR, \\ 87506-370, Brazil. \\ ${ }^{\text {b} C e n t r o ~ d e ~ E n g e n h a r i a s ~ e ~ C i e ̂ n c i a s ~ E x a t a s, ~ U n i v e r s i d a d e ~ E s t a d u a l ~ d o ~ O e s t e ~ d o ~ P a r a n a ́ ~(U N I O E S T E), ~ F a c u l d a d e ~ S t r e e t ~ 645, ~ J a r d i m ~ L a ~}$ \\ Salle, Toledo, PR, 85903-000, Brazil.

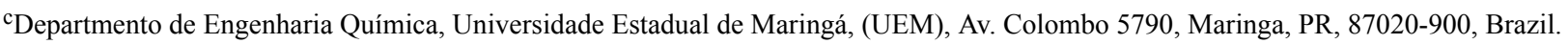 \\ ${ }^{\star}$ Corresponding author: camiladasilva.eq@gmail.com
}

Submitted: January 07, 2020; Accepted: February 26, 2020; Published online: March 3, 2021

SUMMARY: In this study, the production of fatty acid ethyl esters (FAEE) from macauba pulp oil and pressurized ethanol was investigated. The experiments were conducted without the addition of catalyst, at $20 \mathrm{MPa}$, to determine the effect of temperature (200 to $300{ }^{\circ} \mathrm{C}$ ) and the oil to ethanol mass ratio (1:1 and 1:2) on the FAEE content and different residence times (10 to $\left.45 \mathrm{~min}\right)$. The effect of the addition of $n$-hexane to the oil $(20 \mathrm{wt} \%)$ as a co-solvent was also evaluated. The use of high temperatures $\left(275\right.$ and $\left.300{ }^{\circ} \mathrm{C}\right)$ resulted in high FAEE content $(\sim 90 \%)$. Increasing the amount of ethanol in the reaction medium contributed to the formation of esters only at operating temperatures of 200 to $250{ }^{\circ} \mathrm{C}$. It was also observed that with the addition of co-solvent (in the oil) it was possible to obtain high amounts of FAEE in a shorter reaction time. In addition, a low content of unreacted compounds $(\sim 8.0 \%)$ and the conversion of $\sim 90$ and $99 \%$ of the free fatty acids and triglycerides were observed, respectively.

KEYWORDS: Acrocomia aculeate; Catalyst-free; Continuous; Ethanol

RESUMEN: Producción sin catalizador de ésteres etilicos de ácidos grasos (FAEE) a partir de aceite de pulpa de macauba. En este estudio, se investigó la producción de ésteres etílicos de ácidos grasos (FAEE) a partir de aceite de pulpa de macauba y etanol presurizado. Los experimentos se realizaron, sin la adición de catalizador, a $20 \mathrm{MPa}$, para determinar el efecto de la temperatura (200 a $\left.300{ }^{\circ} \mathrm{C}\right)$ y la relación de masa de aceite a etanol (1:1 y 1:2) en el contenido de FAEE, aplicando diferentes tiempos de residencia (10 a $45 \mathrm{~min}$ ). También se evaluó el efecto de la adición de n-hexano al aceite ( $20 \%$ en peso) como co-disolvente. El uso de altas temperaturas $\left(275\right.$ y $\left.300{ }^{\circ} \mathrm{C}\right)$ dio como resultado un alto contenido de FAEE ( 90\%). El aumento de la cantidad de etanol en el medio de reacción contribuyó a la formación de ésteres solo a temperaturas de funcionamiento de 200 a $250{ }^{\circ} \mathrm{C}$. También se observó que con la adición de co-disolvente (en el aceite) era posible obtener altas cantidades de FAEE en un tiempo de reacción más corto. Además, se observó un bajo contenido de compuestos sin reaccionar $(\sim 8,0 \%)$ y la conversión de $\sim 90$ y $99 \%$ de ácidos grasos libres y triglicéridos, respectivamente.

PALABRAS CLAVES: Acrocomia aculeate; Continuo; Etanol; Libre de catalizador

Conflict of interest: The authors declare that there is no conflict of interest.

Citation/Cómo citar este artículo: Silva C, Colonelli TAS, Trentini CP, Postaue N, Zempulski DA, Cardozo-Filho L, Silva EA. 2021. Catalyst-free production of fatty acid ethyl esters (FAEE) from macauba pulp oil. Grasas Aceites 72 (1), e398. https://doi.org/10.3989/ gya.0103201

Copyright: (C2021 CSIC. This is an open-access article distributed under the terms of the Creative Commons Attribution 4.0 International (CC BY 4.0) License. 


\section{INTRODUCTION}

Macauba (Acrocomia aculeata) is a promising oleaginous plant for the production of biodiesel, mainly due to its high oil content, with $23-46 \%$ in the pulp (Evaristo et al., 2016; Lescano et al., 2015) and 43-64\% in the kernel (Evaristo et al., 2016; Nunes et al., 2018). Several reports indicate that the oil extracted from the pulp of macauba presents a high content in free fatty acids (FFA), as observed by Dona et al., (2013) and Visioli et al., (2018), who reported 79.24 and $65.20 \%$ of free fatty acids (FFA) in macauba pulp oil, respectively. The oil is often obtained by pressing and filtration without the need for refining steps (Colonelli et al., 2017). Thus, the conventional method involving the use of homogeneous alkaline catalysts is not applicable for the transformation of this oil into biodiesel, since the presence of FFA neutralizes the catalyst and also produces soap emulsions, which hinders the separation of glycerol (Patil and Deng, 2009).

Thus, other strategies need to be adopted for the synthesis of biodiesel using low quality raw materials, particularly when high concentrations of free fatty acids are present (Mardhiah et al., 2017). Reactions using alcohol under pressurized conditions have been widely investigated for biodiesel production (Visioli et al., 2016; Santos et al., 2017; Trentini et al., 2018). These are associated with the same energy cost as reactions conducted at low pressures using a basic homogeneous catalyst and generate a product with higher purity (Demirbas, 2002), eliminating the need for separation from the catalyst. In this method, high yields of esters are obtained without the use of catalysts in a relatively short time (Nan et al., 2015) since, under conditions of high temperature and pressure, the miscibility of the triglycerides with the alcohol increases due to the decreasing polarity of the alcohol (Farobie and Matsumura, 2017; Kusdiana and Saka, 2004; Liu et al., 2018; Osmieri et al., 2017), which also behaves as an acid catalyst in the reaction besides being a solvent (Kusdiana and Saka, 2004). Another advantage to this method is the efficiency and good results which have been reported for reactions where the oil had a high content in free fatty acids (Postaue et al., 2019; Trentini et al., 2018; Visioli et al., 2018). Thus, this appears to be a viable alternative for studies on macauba pulp oil.
The efficiency of the reaction under pressurized conditions is dependent on the adjustment of the operating variables (pressure, temperature and time), the nature of the raw material (oil and alcohol), the oil-to-alcohol ratio used and the additives added to the reaction medium. The reaction is commonly conducted at pressures in the order of $20 \mathrm{MPa}$ at temperatures between 275 and $350{ }^{\circ} \mathrm{C}$ (Silva and Oliveira, 2014).

The amount of alcohol used in the process is higher than that of the stoichiometric oil-toalcohol molar ratio of 1:3, since an excess of alcohol will favor the formation of the esters, shifting the reaction toward the formation of products (Colonelli et al., 2017). This is because there is an increase in the miscibility and the area of contact between the substrates, which benefits the production of esters (Musa, 2016). Some authors have reported that the use of an oil-toalcohol molar ratio of 1:40 (which equates to a mass ratio of $\sim 1: 2$ ) gives the highest ester yield (Silva et al., 2007; Trentini et al., 2018). However, other authors have found that the formation of esters was favored up to an oil-toalcohol molar ratio of 1:20 (mass ratio of $\sim 1: 1$ ) (Colonelli et al., 2017; Silva et al., 2010; Trentin et al., 2011).

Another aspect to be considered is the addition of a co-solvent to the reaction medium, which can act to improve the operating conditions of the technology using alcohol under sub- and supercritical conditions. This generally involves the reduction of some adjustable parameters of the reaction, such as temperature, pressure, residence time and/or oil-to-alcohol ratio (Akkarawatkhoosith et al., 2019c, 2019a; Osmieri et al., 2017; Tobar and Núñez, 2018). In addition, the miscibility and solubility of the reaction mixture are also improved (Akkarawatkhoosith et al., 2019a, 2019b; Đokić-Stojanović1 et al., 2019; Muppaneni et al., 2013), ensuring a high production of esters in a short period of time and without the use of a catalyst (Lim and Lee, 2013). Several co-solvents are cited in the literature. Notably, the use of $n$-hexane has proved to be efficient for reactions under supercritical conditions without the use of a catalyst (Abdala et al., 2014a; Colonelli et al., 2017; Lim and Lee, 2013; Muppaneni et al., 2013; Silva and Oliveira, 2014), besides reducing the viscosity of the reaction mixture and allowing the production in a continuous process (Sawangkeaw et al., 2011). 
Recently, obtaining oil esters from macauba pulp in a catalyst-free medium using pressurized ethanol was reported by Colonelli et al., (2017). These authors found that the addition of a cosolvent ( $n$-hexane) and the use of higher amounts of alcohol in the reaction medium were the variables that had the greatest influence on the formation of esters. However, the effects of these variables were observed in a fixed residence time.

In this context, the objective of this study was to evaluate the kinetics of ester production from macauba pulp oil (MPO) using ethanol under pressurized conditions and without the use of a catalyst. Experiments were carried out at different temperatures $\left(200{ }^{\circ} \mathrm{C}\right.$ to $\left.300{ }^{\circ} \mathrm{C}\right)$ and the influence of adding a greater amount of ethanol to the reaction medium was evaluated. The effect of the addition of a co-solvent ( $n$-hexane) and the ester yield at different residence times were also investigated.

\section{MATERIALS AND METHODS}

\subsection{Materials}

Macauba pulp oil (Cocal - Brasil), ethanol (JT Baker $99.8 \%$ ) and $n$-hexane (Vetec 98.5\%) were used for the reaction. The fatty acid composition of macauba pulp oil used in this study was previously reported (Colonelli et al., 2017), with the oil presenting predominance of oleic $(70 \%)$ and palmitic acids (13\%). The oil has FFA content of $70.26 \pm 0.05 \mathrm{wt} \%$ and water content of $0.76 \pm$ $0.001 \mathrm{wt} \%$. For analysis of the reaction products, standard analytical methyl heptadecanoate (Sigma Aldrich, 99.9\%) and heptane (F Maia, 95\%) were used.

\subsection{Reaction procedure}

In order to carry out the reaction between macauba pulp oil and ethanol, the mixture of these substrates was fed by a high-pressure liquid pump in a reactor operated in continuous mode. For reactions with $n$-hexane, the co-solvent was added directly into the reaction mixture before pumping. The reactor was at the test temperature and after filling the system, it was pressurized. The residence time was calculated by the ratio between the reactor volume and the feed rate of the reaction mixture. Before collection, the reaction mixture was cooled to $15{ }^{\circ} \mathrm{C}$ by a thermostatic bath. The apparatus and experimental procedure is described in greater detail by Mello et al., (2017) and Visioli et al., (2016) and the experiment for each experimental condition was performed at least in duplicate.

Samples were collected after the residence time for each reaction had been reached, and the excess ethanol was removed at $80{ }^{\circ} \mathrm{C}$. To remove the glycerol formed the procedure described by Trentini et al., (2018) was used.

\subsection{Analytical methods}

To determine ester content, the samples were diluted in heptane and the internal standard (methyl heptadecanoate) was added and then the samples were injected, in triplicate, in the gas chromatograph (Agilent GC 7890), equipped with flame ionization detector and capillary column (ZB-WAX, $30 \mathrm{~m} \times 0.25 \mathrm{~mm} \times 0.1 \mu \mathrm{m}$ ), using the chromatographic conditions reported by Colonelli et al., (2017). The quantification of the ester content in the samples followed the standard UNE-EN 14103 method (2003), using Equation 1 to calculate the ethyl ester content:

$$
\text { Esters content }(\%)=\left(\frac{\Sigma A}{A P} \frac{C P}{C A}\right) \times 100
$$

where $\Sigma \mathrm{A}$ is the sum of the peak areas corresponding to the esters, AP is the area for the methyl heptadecanoate, $\mathrm{CP}$ and $\mathrm{CA}$ are the concentrations of the methyl heptadecanoate and injected sample, respectively.

In order to determine the contents in mono-, diand triglycerides, $100 \mathrm{mg}$ of sample were derivatized with MSTFA (15 $\mathrm{min}$ at room temperature) (Standard UNE-EN 14105, 2003) and then to a concentration of $3 \mathrm{mg} \cdot \mathrm{mL}^{-1}$. The diluted sample $(2 \mu \mathrm{L})$ was analyzed with a gas chromatograph (Shimadzu, GC-2010 Plus) equipped with a capillary column (Zebron ZB-5HT, $10 \mathrm{~m} \times 0.32 \mathrm{~mm} \times 0.10 \mu \mathrm{m})$, flame ionization detector and on-column injector. The information concerning oven temperature gradient, detector temperature and the heating program for the injector were presented by Trentini et al., (2019). Calibration curves were constructed using chromatographic standards of triolein, diolein and monolein for the quantification of the compounds. FFA content was determined from the acid-base titration method as recommended by AOCS Ca 5a-40 (American Oil Chemists' Society, 1990). 


\section{RESULTS AND DISCUSSION}

\subsection{Ethyl ester content}

Figure 1 shows the results from the experiments conducted with a mass ratio of MPOto-ethanol of $1: 1$, as well as the effect of increasing the ratio to $1: 2$ and adding $20 \mathrm{wt} \%$ of co-solvent ( $n$-hexane) at a ratio of $1: 1$, at temperatures of 200 to $300{ }^{\circ} \mathrm{C}$. The mass ratios of MPO-to-ethanol of 1:1 and 1:2 are equivalent to molar ratios of triglycerides-to-ethanol of $\sim 40$ and 122 and of free fatty acids-to-ethanol of 9 and 18 , respectively.

\subsubsection{Effect of temperature}

In the overall analysis of the data shown in Figure 1 it can be seen that an increase in temperature led to higher ester yields. When the temperature was increased from 200 to $250{ }^{\circ} \mathrm{C}$ and from 250 to $300{ }^{\circ} \mathrm{C}$, with a residence time of $10 \mathrm{~min}$, it was possible to obtain an increase in the ester content in the ratios of $\sim 2.35$ and $\sim 1.15$, respectively, for the three reaction media evaluated. The temperature effect is significant $(\mathrm{p}<0.05)$ up to the residence time of $45 \mathrm{~min}$ (analysis not shown in Figure 1).

In reactions at high temperatures, changes in the solubility, density, dielectric constant and solvation of the mixture in the reaction medium occur (Farobie and Matsumura, 2017). This favors a reduction in the mass transfer limitations and increases the reaction rate (Abbaszaadeh et al., 2012; Pinnarat and Savage, 2010). In addition, near the critical temperature, the polarity of the alcohol decreases, and the alcohol starts to solvate the non-polar triglycerides, forming a practically homogeneous mixture (Srivastava, Paul, and Goud, 2018), which allows higher ester yields to be obtained.

Tobar and Núñez (2018) showed that the reaction kinetics are affected by increasing temperature due to an increase in the kinetic energy of the particles and the relative probability of collisions between them.

In a study conducted by Silva et al., (2014), increased ester yields were observed on increasing the temperature from 250 to $300{ }^{\circ} \mathrm{C}$, with a difference of $\sim 42 \%$ in only $10 \mathrm{~min}$ of reaction. A similar result was reported by Santos et al., (2018) with a $30 \%$ increase in the ester yield for the same temperature range. In addition, Zhou et al., (2017) and Akkarawatkhoosith et al., (2019a) obtained an increased ester content of $\sim 60 \%$ on increasing the operating temperature from 250 to $300{ }^{\circ} \mathrm{C}$.

Under the conditions where ethanol was below its critical temperature $\left(243.2{ }^{\circ} \mathrm{C}\right)$, the results demonstrated an FAEE content of 30 to $60 \%$. This is due to the high concentration of FFA in the macauba oil used $(70.26 \%)$, resulting in the esterification reaction predominating, since FFAs are more reactive than triglycerides (Go et al., 2014; Vieitez et al., 2012).

Pinnarat and Savage (2010) studied noncatalytic esterification and reported that an ester content of $70 \%$ was obtained at $230{ }^{\circ} \mathrm{C}$ with a residence time of $80 \mathrm{~min}$ and pressure of $5.2 \mathrm{MPa}$. Go et al., (2014) reported an ester yield of $\sim 60 \%$ with the reaction conducted at $200{ }^{\circ} \mathrm{C}$ for $30 \mathrm{~min}$ at a pressure of $2.8 \mathrm{MPa}$. At the same temperature but with a pressure of $20 \mathrm{MPa}$, Abdala et al., (2014b) achieved $\sim 70 \%$ conversion of oleic acids to esters in only $10 \mathrm{~min}$ of reaction. Santos et al., (2017) obtained an esters content of $\sim 75 \%$ at $220^{\circ} \mathrm{C}$ and $10 \mathrm{MPa}$ with $80 \mathrm{~min}$ of reaction. Jesus et al., (2018) observed that the reaction between oleic acid and ethanol yielded $\sim 66 \%$ esters at $200{ }^{\circ} \mathrm{C}$ with a reaction time of $30 \mathrm{~min}$ and pressure of $15 \mathrm{MPa}$.

\subsubsection{Effect of oil to ethanol mass ratio}

Increasing the MPO-to-ethanol mass ratio from $1: 1$ to $1: 2$ had a more pronounced effect on the formation of esters for the reactions conducted at temperatures of 200 to $250{ }^{\circ} \mathrm{C}$, particularly at the shortest times evaluated (10 and $15 \mathrm{~min})$. At the highest temperatures considered, that is $275{ }^{\circ} \mathrm{C}$ (Figure 1d) and $300^{\circ} \mathrm{C}$ (Figure 1e), the increase in the amount of alcohol in the reaction medium did not influence the FAEE content.

A greater amount of alcohol in the reaction boosts the formation of the products, since increasing the volume of ethanol available in the medium results in a decrease in the critical temperature of the reaction mixture (Osmieri et al., 2017), promoting the occurrence of the reaction occurring in a homogeneous phase region and increasing the reaction kinetics. MPO is mainly composed of FFA and esterification predominates in the reaction medium. As reported by Santos et al., (2017), this reaction occurs in a single homogeneous phase at $10 \mathrm{MPa}$ with an FFA-to-ethanol molar ratio of $1: 1$ to $30: 1$ from 220 to $280{ }^{\circ} \mathrm{C}$.

The alcohol concentration has little effect at higher operating temperatures, as observed at 275 

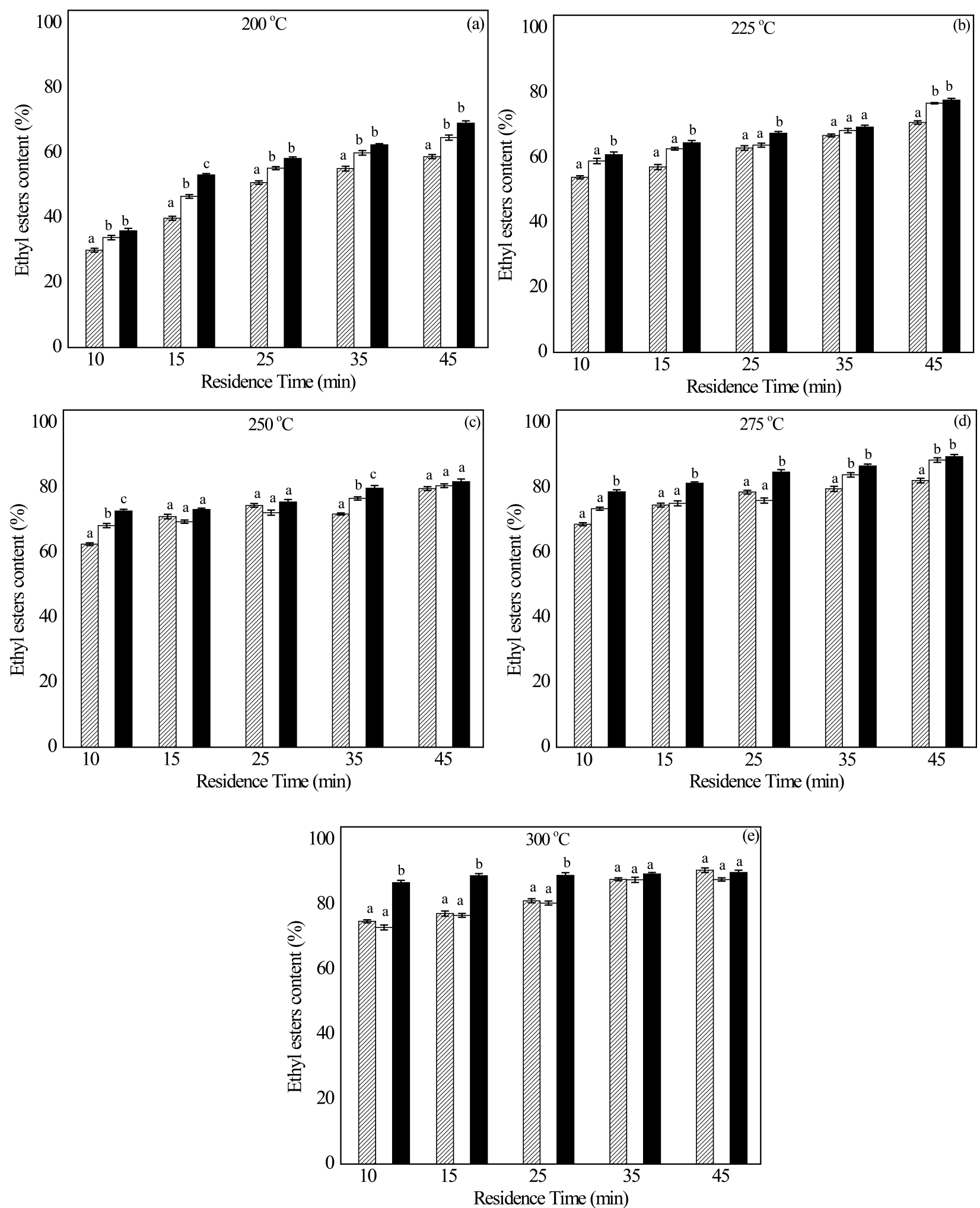

Figure 1. Ethyl ester contents of macauba pulp oil obtained at different temperatures: (a) $200{ }^{\circ} \mathrm{C}$, (b) $225{ }^{\circ} \mathrm{C}$, (c) $250{ }^{\circ} \mathrm{C}$, (c) $275^{\circ} \mathrm{C}$ and (e) $300{ }^{\circ} \mathrm{C}$ at $20 \mathrm{MPa}$, MPO-to-ethanol mass ratio of 1:1 ( solvent (in oil) ( $)$. The values in the graphs represent the means of two determinations, with $\mathrm{SD}<2.0 \%$. Means followed by the same lowercase letters (with the same residence time) did not differ statistically $(\mathrm{p}>0.05)$ using ANOVA (Tukey’s test). 
and $300{ }^{\circ} \mathrm{C}$ (Figure 1), this effect occurs due to the increase in the critical pressure in the mixture, which makes it necessary to use high pressure to obtain a homogeneous phase, as noted by Nan et al., (2015) who obtained similar ester yields at $310^{\circ} \mathrm{C}$, after $30 \mathrm{~min}$ at $14 \mathrm{MPa}$, using microalgae oil-to-ethanol molar ratios of 1:26 and 1:42. The experiments conducted by Bezerra et al., (2018) also provided similar conversion to ethyl esters for oil:ethanol molar ratios of 1:20 and 1:40 at $350{ }^{\circ} \mathrm{C}$, after $40 \mathrm{~min}$ at $20 \mathrm{MPa}$. A similar result was obtained by Costa et al., (2019) on raising the oil:methanol molar ratio from $1: 21$ to $1: 41$, at $300{ }^{\circ} \mathrm{C}$, for $10 \mathrm{~min}$ of reaction at $20 \mathrm{MPa}$.

At lower temperatures $\left(200\right.$ to $\left.250{ }^{\circ} \mathrm{C}\right)$ the effect of the ratio between the lipids (triglycerides or FFA) and the alcohol in the matrix can be noted (Figure 1). Mello et al., (2017) reported a 12\% increase in the ethyl ester yield on increasing the ratio of alcohol to crambe oil hydrolyzate from 12:1 to $15: 1$ (molar basis) in a reaction conducted at $275{ }^{\circ} \mathrm{C}$, for $10 \mathrm{~min}$ at $15 \mathrm{MPa}$. Jesus et al., (2018) conducted the reaction at $250{ }^{\circ} \mathrm{C}$ and

$15 \mathrm{MPa}$ and found that on increasing the ethanol:oleic acid molar ratio from 1:1 to $6: 1$ the conversion of FFA to esters increased by $22 \%$.

\subsubsection{Effect of co-solvent}

The addition of $20 \mathrm{wt} \%$ of co-solvent to the reaction mixture (with an oil-to- ethanol mass ratio of 1:1) promoted an improvement in ester production. Thus, for a residence time of $10 \mathrm{~min}$ it was possible to obtain increases of 30 to $36 \%$ and 75 to $87 \%$ in the ester content at 200 and $300{ }^{\circ} \mathrm{C}$, respectively. The use of a co-solvent improves the mutual solubility between the alcohol and the oil (Tobar and Núñez, 2018), allowing for the presence of a homogeneous phase (Osmieri et al., 2017), increasing the reaction rate and making it possible to obtain high ester yields at moderate temperatures (Maçaira et al., 2014).

Zhou et al., (2017) performed a coupled extraction and reaction process. When the reaction was conducted at $340{ }^{\circ} \mathrm{C}$, for $120 \mathrm{~min}$, with an $n$-hexane flow of $0.2 \mathrm{~mL} \cdot \mathrm{min}^{-1}$, there was an increase of $63 \%$ in ester yield compared to the reaction without the addition of the co-solvent. In research conducted by Tobar and Núñez (2018), the highest yield of ethyl esters $(68 \%)$ was obtained with the addition of $\mathrm{CO}_{2}\left(0.001 \mathrm{~g} \mathrm{CO}_{2}\right.$ per $\mathrm{g}$ of ethanol) as a co-solvent at $300{ }^{\circ} \mathrm{C}$ and
20 MPa. Akkarawatkhoosith et al., (2019c) reported that an iso-propanol:oil weight ratio of $0.1: 1$ for only $3 \mathrm{~min}$ at $350{ }^{\circ} \mathrm{C}$ gave a $37 \%$ increase in the ester yield. The same research group (Akkarawatkhoosith et al., 2019b) also found that in the reaction conducted at $300{ }^{\circ} \mathrm{C}$ for $4 \mathrm{~min}$ the addition of a co-solvent $(55 \mathrm{wt} \%$ ethyl acetate) promoted an increase in the ethyl ester production of $\sim 68 \%$ compared to the reaction with no co-solvent added.

It should be noted that adding more alcohol to the process would significantly increase the production costs, as the ethanol $(99.5 \%)$ used for this purpose is $\sim 21 \%$ more expensive than $n$-hexane $(95 \%)$, according to the company Tedia Brazil $\AA$. Thus, the costs related to increasing the oil-to-ethanol mass ratio to $1: 2$ would be $\sim 85 \%$ higher than using the mass ratio of $1: 1$ with $20 \mathrm{wt} \%$ of $n$-hexane (basis of calculation: $1 \mathrm{~L}$ of reaction mixture). However, it needs to be considered that high ester content $(\sim 89 \%)$ can be obtained in a relatively short time $(15 \mathrm{~min})$ at $300{ }^{\circ} \mathrm{C}$, further enhancing the benefits of using the co-solvent. In addition, as noted by Sawangkeaw et al., (2011), $n$-hexane, the solvent most commonly used in the extraction of vegetable oils, can be removed after the oil extraction and employed in the production of biodiesel.

\subsection{Triglyceride, diglyceride and monoglyceride contents}

In the samples obtained at $300{ }^{\circ} \mathrm{C}$, the triglyceride (TG), diglyceride (TG), monoglyceride (MG) and free fatty acid (FFA) contents were determined, as shown in Figure 2, considering that the highest levels of FAEE were obtained at this temperature. The contents in these compounds in the MPO were also determined at: $18.42 \pm 0.15 \mathrm{wt} \%, 15.2 \pm 0.62 \mathrm{wt} \%, 3.85 \pm$ $0.12 \mathrm{wt} \%$ and $70.26 \pm 0.05 \mathrm{wt} \%$ of TG, DG, MG and FFA, respectively. In general, the increase in mass ratio and addition of co-solvent did not influence the conversion of $\mathrm{TG}$ or the formation of $\mathrm{DG}$. The reaction conducted with a mass ratio of MPO-to-ethanol of 1:1, showed a higher concentration of MG when compared to the others. It can also be seen that there was a higher consumption of FFA for the reaction with a mass ratio MPO-to-ethanol of 1:2.

For all conditions evaluated, high TG conversions were achieved, with contents in these 

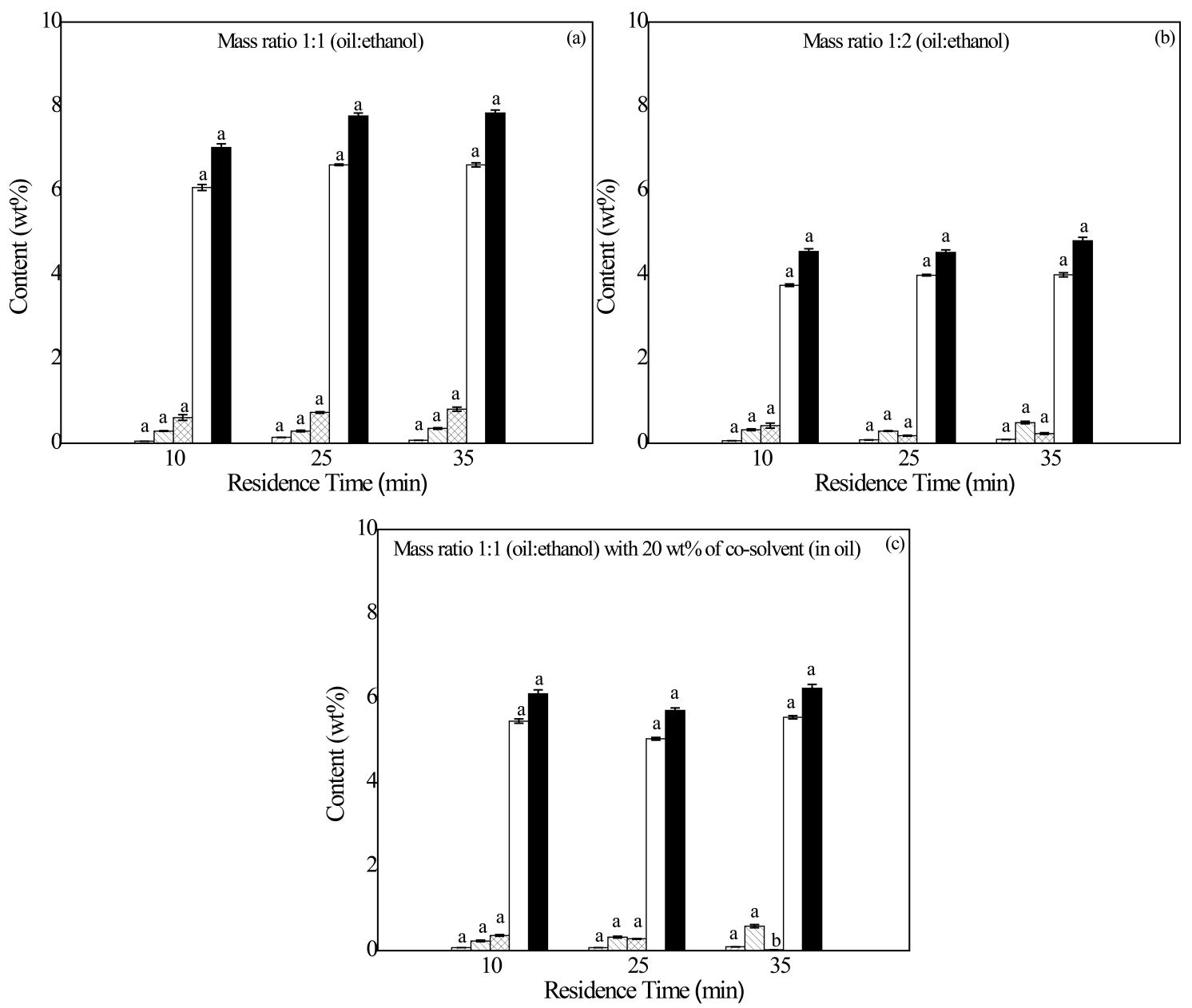

FIGURE 2. Triglyceride ( MPO-to-ethanol mass ratio of (a) 1:1 and (b) 1:2, and (c) MPO-to-ethanol mass ratio of 1:1 with $20 \mathrm{wt} \%$ of co-solvent (in oil). The values in the graphs represent the means of two determinations, with $\mathrm{SD}<1.0 \mathrm{wt} \%$. Means followed by the same lowercase letters (for the same compound) did not differ statistically $(\mathrm{p}>0.05)$ using ANOVA (Tukey's test).

compounds in the samples obtained being below $0.14 \mathrm{wt} \%$. In other studies on the transesterification reaction under pressurized conditions conducted at the same temperature, the TG contents of 0.2 to $22 \mathrm{wt} \%$ (Santos et al., 2018; Trentin et al., 2011; Trentini et al., 2019; Vieitez et al., 2010) were detected under the conditions that provided maximum ester yields.

The remaining FFA contents in the samples ranged from 4.0 to $6.6 \mathrm{wt} \%$, which correspond to an FFA conversion of above $90 \%$. A similar result was obtained by Visioli et al., (2016) for conversion under the thermodynamic equilibrium in the esterification reaction of soybean oil deodorizer distillate with pressurized ethanol. Vieitez et al., (2012) performed the supercritical alcoholysis of raw materials with 0 to $100 \mathrm{wt} \%$ of
FFA and achieved a maximum conversion of FFA to ethyl esters of $\sim 90 \%$.

The total amount of unreacted compounds detected was less than $8.0 \mathrm{wt} \%$. Soto et al., (2014) found DG, MG and FFA contents of 11, 3 and $2 \%$, respectively, in the reaction between sunflower oil and methanol with $40 \mathrm{~min}$ of reaction at $18 \mathrm{MPa}$. Ortiz-Martínez et al., (2016) reported a higher value of unreacted compounds, with $\sim 18$ and $27 \%$ of MG and DG, respectively, for the reaction between Pongamia pinnata oil and methanol, with a reaction time of $20 \mathrm{~min}$ at $18 \mathrm{MPa}$. Low contents in MG (2\%), DG (4\%) and TG $(0.2 \%)$ were reported by Trentini et al., (2019) for the reaction between grease trap waste lipids and ethanol, with the addition of $2.5 \mathrm{wt} \%$ water, with a residence time of $30 \mathrm{~min}$ at $20 \mathrm{MPa}$. 


\section{CONCLUSIONS}

Increasing the operating temperature up to $300{ }^{\circ} \mathrm{C}$ for the reaction between macauba pulp oil (MPO) and ethanol led to high ester contents. Moreover, it was found that the reactions conducted at high temperatures $\left(275\right.$ and $\left.300{ }^{\circ} \mathrm{C}\right)$ required less alcohol in the reaction medium in shorter residence times, demonstrating that temperature is a key factor to be considered in studies on the production of esters. The addition of $n$-hexane to the reaction, which increased the diglyceride and monoglyceride contents by only $0.6 \mathrm{wt} \%$, allowed for a reduction in the reaction time of $\sim 44 \%$ and increased the ester production by up to $\sim 25 \%$. The reaction in a pressurized medium without catalyst was effective, and produced low contents in unreacted compounds $(\sim 8.0 \%)$ and high consumption of triglycerides $(\sim 99 \%)$ and free fatty acids $(\sim 90 \%)$. The highest FAEE content $(\sim 90 \%)$ was obtained with an MPO-to-ethanol mass ratio of $1: 1$ with $20 \mathrm{wt} \%$ of co-solvent (in the oil) at $300{ }^{\circ} \mathrm{C}$ after $15 \mathrm{~min}$ of reaction.

\section{ACKNOWLEDGEMENT}

The authors thank $\mathrm{CNPq}$ and Fundação Araucária for financial support.

\section{REFERENCES}

Abbaszaadeh A, Ghobadian B, Omidkhah MR, Najafi G. 2012. Current biodiesel production technologies : A comparative review. Energ. Convers. and Manage. 63, 138-148. https:// doi.org/10.1016/j.enconman.2012.02.027

Abdala ACDA, Colonelli TADS, Trentini CP, Oliveira JV, Cardozo-Filho L, Silva EA, Silva C. 2014a. Effect of additives in the reaction medium on noncatalytic ester production from used frying oil with supercritical ethanol. Ener. Fuels 283122-3128. https://doi.org/10.1021/ ef402253e

Abdala AC, Garcia VA, Trentini CP, CardozoFilho L, Silva EA, Silva C. 2014b. Continuous Catalyst-Free Esterification of Oleic Acid in Compressed Ethanol. Int. J. Chem. Eng. 2014, 1-5. https://doi.org/10.1155/2014/803783

Akkarawatkhoosith N, Kaewchada A, Jaree A. 2019a. Enhancement of continuous supercritical biodiesel production : influence of co-solvent types. Enrgy Proced. 156, 48-52. https://doi.org/10.1016/j.egypro.2018.11.085
Akkarawatkhoosith N, Kaewchada A, Jaree A. 2019b. Production of Biodiesel from Palm Oil under Supercritical Ethanol in the Presence of Ethyl Acetate. Energ. Fuel 33, 5322-5331. research-article. https://doi.org/10.1021/acs.en ergyfuels.9b00641

Akkarawatkhoosith N, Kaewchada A, Jaree A. 2019c. Simultaneous development of biodiesel synthesis and fuel quality via continuous supercritical process with reactive co-solvent. Fuel 237, 117-125. https://doi.org/10.1016/ j.fuel.2018.09.077

American Oil Chemists' Society. Standard Methods for the Analysis of Oils, Fats and Derivatives, International Union of Pure and Applied Chemistry Commission on Oils, Fats and Derivatives $\S$ (1990).

Bezerra FWF, Costa WA, Oliveira MS, Andrade HÁ, Carvalho JRN. 2018. Transesterification of palm pressed-fibers (Elaeis guineensis Jacq.) oil bysupercriticalfluid carbon dioxide with entrainer ethanol. J. Supercrit. Fluids 136, 136-143. https://doi.org/10.1016/j.supflu.20 18.02.020

Colonelli TADS, Trentini CP, Santos KA, Oliveira JV, Cardozo-Filho L, Silva EA, Silva C. 2017. Assessment of process variables on the use of macauba pulp oil as feedstock for the continuous production of ethyl esters under pressurized conditions. Braz. J. Che. Eng. 34, 831-839. https://doi.org/10.1590/0104-6632. 20170343s20150768

Costa WA, Bezerra FWF, Oliveira MS, Andrade HA, Santos APM, Cunha VMB, Junior RN. 2019. Supercritical $\mathrm{CO}_{2}$ extraction and transesterification of the residual oil from industrial palm kernel cake with supercritical methanol. J. Supercrit. Fluids, 147, 179-187. https://doi.org/10.1016/j.supflu.2018.10.012

Demirbas A. 2002. Biodiesel from vegetable oils via transesterification in supercritical methanol. Energ. Convers. and Manage. 43, 2349-2356. https://doi.org/10.1016/S0196-89 04(01)00170-4

Đokić-Stojanović1 DR, Todorović ZB, Troter DZ, Stamenković OS, Veselinović LM, Zdujić MV, Manojlović DD, Veljković VB. 2019. Influence of various co-solvents on the calcium oxide-catalyzed ethanolysis of sunflower oil. $J$. Serbian Chem. Soc. 84, 253-265. https:// doi.org/10.2298/JSC180827007D

Doná G, Cardozo-Filho L, Silva C, Castilhos F. 2013. Biodiesel production using supercritical methyl acetate in a tubular packed bed reactor. 
Fuel Process. Technol. 106, 605-610. https:// doi.org/10.1016/j.fuproc.2012.09.047

Evaristo AB, Grossi JAS, Pimentel LD, Goulart SDM, Martins AD, Santos VL, Motoike S. 2016. Harvest and post-harvest conditions influencing macauba (Acrocomia aculeata) oil quality attributes. Ind. Crops. Prod. 85, 63-73. https://doi.org/10.1016/j.indcrop.2016.02.052

Farobie O, Matsumura Y. 2017. State of the art of biodiesel production under supercritical conditions. Prog. Energy. Combust. Sci. 63, 173-203. https://doi.org/10.1016/j.pecs.2017. 08.001

Go AW, Sutanto S, NguyenThi BT, Cabatingan LK, Ismadji S, Ju Y. 2014. Transesterification of soybean oil with methanol and acetic acid at lower reaction severity under subcritical conditions. Energ. Convers. Manag. 88, 1159-1166. https://doi.org/10.1016/j.enconma n.2014.03.014

Jesus AA, Souza DF, Oliveira JA, Deus MS, Silva MG, Franceschi E, Dariva C. 2018. Mathematical modeling and experimental esterification at supercritical conditions for biodiesel production in a tubular reactor. Energ. Convers. Manag. 171, 1697-1703. https://doi.org/10.1016/j.enconman.2018.0 6.108

Kusdiana D, Saka S. 2004. Effects of water on biodiesel fuel production by supercritical methanol treatment. Bioresour. Technol. 91, 289-295. https://doi.org/10.1016/S0960-8524(0 3)00201-3

Lescano CH, Oliveira IP, Silva LR, Baldivia DS, Sanjinez-Argandonã, EJ, Arruda EJ, Lima FF. 2015. Nutrients content, characterization and oil extraction from Acrocomia aculeata (Jacq.) Lodd . fruits. Afr. J. Food Sci. 9, 113-119. https://doi.org/10.5897/AJFS2014.1212

Lim S, Lee K. 2013. Influences of different cosolvents in simultaneous supercritical extraction and transesterification of Jatropha curcas L . seeds for the production of biodiesel. Chem. Eng. J. 221, 436-445. https:// doi.org/10.1016/j.cej.2013.02.014

Liu J, Nan Y, Huang X, Bond JQ, Tavlarides LL. 2018. Applied Catalysis B: Environmental Continuous esteri fi cation of oleic acid to ethyl oleate under sub / supercritical conditions over $\gamma-\mathrm{Al}_{2} \mathrm{O}_{3}$. Appl. Catal. B 232, 155-163. https://doi.org/10.1016/j.apcatb.2018.03.050

Maçaira J, Santana A, Costa A, Ramirez E, Larrayoz MA. 2014. Process Intensification Using CO2 As Cosolvent under Supercritical
Conditions Applied to the Design of Biodiesel Production. Ind. Eng. Chem. Res. 5 3, 3985-3995. https://doi.org/10.1021/ie402657e

Mardhiah HH, Chyuan H, Masjuki HH, Lim S, Pang YL. 2017. Investigation of carbon-based solid acid catalyst from Jatropha curcas biomass in biodiesel production. Energ. Convers. and Manage. 144, 10-17. https:// doi.org/10.1016/j.enconman.2017.04.038

Mello BTF, Gonçalves JE, Rodrigues GM, Cardozo-Filho L, Silva C. 2017. Hydroesterification of crambe oil (Crambe abyssinica H.) under pressurized conditions. Ind. Crops Prod. 97, 110-119. https://doi.org/ 10.1016/j.indcrop.2016.12.014

Muppaneni T, Reddy HK, Ponnusamy S, Patil PD, Sun Y, Dailey P, Deng S. 2013. Optimization of biodiesel production from palm oil under supercritical ethanol conditions using hexane as co-solvent : A response surface methodology approach. Fuel 107, 633-640. https://doi.org/10.1016/j.fuel.2012. 11.046

Musa IA. 2016. The effects of alcohol to oil molar ratios and the type of alcohol on biodiesel production using transesterification process. Egypt. J. Pet. 25, 21-31. https:// doi.org/10.1016/j.ejpe.2015.06.007

Nan Y, Liu J, Lin R, Tavlarides LL. 2015. Production of biodiesel from microalgae oil (Chlorella protothecoides) by non-catalytic transesterification in supercritical methanol and ethanol: Process optimization. J. Supercrit. Fluids 97, 174-182. https://doi.org/10.1016/ j.supflu.2014.08.025

Nunes ÂA, Buccini DF, Jaques JAS, Portugal LC, Guimarães RCA, Favaro SP, Carvalho CME. 2018. Effect of Acrocomia aculeata Kernel Oil on Adiposity in Type 2 Diabetic Rats. Plant. Foods Hum. Nutr. 73, 61-67. https://doi.org/ 10.1007/s11130-017-0648-8

Ortiz-Martínez VM, Salar-García MJ, PalaciosNereo FJ, Olivares-Carrillo P, Quesada-Medina J, Ríos APDL, Hernández-Fernández FJ. 2016. In-depth study of the transesterification reaction of Pongamia pinnata oil for biodiesel production using catalyst-free supercritical methanol process. J. Supercrit. Fluids 113, 23-30. https://doi.org/10.1016/j.supflu.2016. 03.009

Osmieri L, Esfahani RAM, Recasens F. 2017. Continuous biodiesel production in supercritical two-step process: phase equilibrium and process design. J. Supercrit. 
Fluids 124, 57-71. https://doi.org/10.1016/ j.supflu.2017.01.010

Patil PD, Deng S. 2009. Optimization of biodiesel production from edible and non-edible vegetable oils. Fuel 88, 1302-1306. https:// doi.org/10.1016/j.fuel.2009.01.016

Pinnarat T, Savage PE. 2010. Noncatalytic esterification of oleic acid in ethanol. $J$. Supercrit. Fluids, 53, 53-59. https://doi.org/ 10.1016/j.supflu.2010.02.008

Postaue N, Trentini CP, Mello BTF, CardozoFilho L, Silva C. 2019. Continuous catalystfree interesterification of crambe oil using methyl acetate under pressurized conditions. Energ. Convers. and Manage. 187, 398-406. https://doi.org/10.1016/j.enconman.2019.03.0 46

Santos KC, Hamerski F, Voll FAP, Corazza ML. 2018. Experimental and kinetic modeling of acid oil (trans)esterification in supercritical ethanol. Fuel 224, 489-498. https://doi.org/ 10.1016/j.fuel.2018.03.102

Santos PR, Pedersen FA, Ramos LP, Corazza ML. 2017. Esterification of fatty acids with supercritical ethanol in a continuous tubular reactor. J. Supercrit. Fluids 126, 25-36. https:// doi.org/10.1016/j.supflu.2017.03.002

Sawangkeaw R, Bunyakiat K, Ngamprasertsith S. 2011. Continuous production of biodiesel with supercritical methanol : Optimization of a scale-up plug fl ow reactor by response surface methodology. Fuel Process. Technol. 92, 2285-2292. https://doi.org/10.1016/j.fuproc.2 011.07 .014

Silva C, Castilhos F, Oliveira JV, Cardozo-Filho L, Trentin CM, Lima AP, Oliveira JV. 2010. Continuous production of soybean biodiesel with compressed ethanol in a microtube reactor. Fuel Process. Technol. 91, 1274-1281. https://doi.org/10.1016/j.fuproc.2010.12.016

Silva C, Colonelli TAS, Silva EA, Cabral VF, Oliveira JV, Cardozo-Filho L. 2014. Continuous catalyst-free production of esters from Jatropha curcas L. oil under supercritical ethanol. Braz. J. Chem. Eng. 31727-735. https://doi.org/10.1590/0104-6632.20140313s 00002709

Silva C, Oliveira JV. 2014. Biodiesel production through non-catalytic supercritical transesterification: Current state and perspectives. Braz. J. Chem. Eng. 31, 271-285. https://doi.org/10.1590/0104-6632.20140312s 00002616
Silva C, Weschenfelder T, Rovani S, Corazza FC, Corazza ML, Dariva C, Oliveira JV. 2007. Continuous Production of Fatty Acid Ethyl Esters from Soybean Oil in Compressed Ethanol. Ind. Eng. Chem. Res. 46, 5304-5309. https://doi.org/10.1021/ie070310r

Soto G, Hegel P, Pereda S. 2014. Supercritical production and fractionation of fatty acid esters and acylglycerols. J. Supercrit. Fluids 93, 74-81. https://doi.org/10.1016/j.supflu.2014. 04.017

Standard UNE-EN 14105. 2003. Determinación de los contenidos de glicerol libre y total y de mono-, di- y triglicéridos. Madrid, Spain.

Srivastava G, Paul AK, Goud VV. 2018. Optimization of non-catalytic transesterification of microalgae oil to biodiesel under supercritical methanol condition. Energy. Conver. Manag. 156, 269-278. https://doi.org/10.1016/j.enconman.2 017.10 .093

Tobar M, Núñez GA. 2018. Supercritical transeterification of microalgae triglycerides for biodiesel production: Effect of alcohol type and co-solvent. J. Supercrit. Fluids 137, 50-56. https://doi.org/10.1016/j.supflu.2018.03.008

Trentin CM, Lima AP, Alkimim IP, Silva C, Castilhos F, Mazutti MA, Oliveira JV. 2011. Continuous production of soybean biodiesel with compressed ethanol in a microtube reactor using carbon dioxide as co-solvent. Fuel Process. Technol. 92, 952-958. https://doi.org/ 10.1016/j.fuproc.2010.12.016

Trentini CP, Fonseca JM, Cardozo-Filho L, Reis R, Sampaio SC, Silva C. 2018. Assessment of continuous catalyst-free production of ethyl esters from grease trap waste. J. Supercrit. Fluids 136, 157-163. https://doi.org/10.1016/ j.supflu.2018.02.018

Trentini CP, Postaue N, Cardozo-Filho L, Reis RR, Sampaio SC, Silva C. 2019. Production of esters from grease trap waste lipids under supercritical conditins: Effect of water addition on ethanol. J. Supercrit. Fluids 147, 16. https:// doi.org/10.1016/j.supflu.2019.02.008

Vieitez I, Irigaray B, Casullo P, Pardo MJ, Grompone MA, Jachmanián I. 2012. Effect of free fatty acids on the efficiency of the supercritical ethanolysis of vegetable oils from different origins. Energy. and Fuels 26, 1946-1951. https://doi.org/10.1021/ef201977s

Vieitez I, Silva C, Alckmin I, Borges GR, Corazza FC, Oliveira JV, Jachmanián, I. 2010. Continuous catalyst-free methanolysis and 
ethanolysis of soybean oil under supercritical alcohol/water mixtures. Renew. Energ. 35, 1976-1981. https://doi.org/10.1016/j.renene. 2010.01.027

Visioli LJ, Castilhos F, Cardozo-Filho L, Mello BTF, Silva C. 2016. Production of esters from soybean oil deodorizer distillate in pressurized ethanol. Fuel Process. Technol. 149, 326-331. https://doi.org/10.1016/j.fuproc.2016.04.038

Visioli LJ, Trentini CP, Castilhos F, Silva C. 2018. Esters production in continuous reactor from macauba pulp oil using methyl acetate in pressurized conditions. J. Supercrit. Fluids 140, 238-247. https://doi.org/10.1016/j.supflu. 2018.06.018

Zhou D, Qiao B, Li G, Xue S, Yin J. 2017. Continuous production of biodiesel from microalgae by extraction coupling with transesterification under supercritical conditions. Bioresour. Technol. 238, 609-615. https://doi.org/10.1016/j.biortech.2017.04.097 